\title{
New slide test for infectious mononucleosis
}

\author{
R. J. L. DAVIDSON
}

From the Laboratory, City Hospital, Aberdeen

SYNOPSIS The rapid and simple slide test for infectious mononucleosis designed by Hoff and Bauer (1965) is designed and compared with a modified sheep-cell slide screening test (Maloney and Malzone, 1949) and the differentenial absorption technique (Davidson, 1937). The claim of Hoff and Bauer that their test is more 'specific' is substantiated. Brief clinical histories illustrate the argument.

Until the aetiology of infectious mononucleosis is ultimately defined, its diagnosis must necessarily be based on a composite of clinical, haematological, and serological criteria (Bender, 1958; Hoagland, 1960). These criteria are all non-specific and their pattern of positivity may vary, not only in different patients but also in the same patient according to the phase of the illness (Evans, 1960).

Since the first serological test for infectious mononucleosis was introduced by Paul and Bunnell in 1932, many additional and modified serological procedures have been described (Davidson and Lee, 1964). Comparative studies of the various techniques have often shown the results to be at variance, not only with each other, but also with the clinical and haematological findings.

Recently Hoff and Bauer (1965) described a rapid and simple slide test for infectious mononucleosis using a $4 \%$ saline suspension of formalin-treated horse erythrocytes as antigen. This paper describes a study undertaken to evaluate this new technique and to compare it with a modified sheep-cell slide screening test (Moloney and Malzone, 1949) and the differential absorption technique (Davidson, 1937).

\section{MATERIAL AND METHODS}

DENCO TEST FOR INFECTIOUS MONONUCLEOSIS This rapid slide test, known as the Mono-test in the U.S.A., was carried out according to the method of Hoff and Bauer (1965). The reagents were supplied through the courtesy of Denver Laboratories, Ltd., London.

SHEEP-CELL SCREENING TEST The screening procedure used in this laboratory for many years is a modification of the technique described by Moloney and Malzone (1949). Sheep cells, obtained twice weekly from the local abattoir, are washed three times with a minimum of 10 volumes of normal saline, centrifuged, and the packed cells are stored at $4^{\circ} \mathrm{C}$. One drop of the test serum is Received for publication 9 November 1966. added to one drop of a freshly prepared $10 \%$ suspension of the sheep cells on a glass slide and thoroughly mixed. Any macroscopic agglutination appearing within one minute is accepted as presumptive evidence of infectious mononucleosis and the serum is then tested by the differential absorption technique.

DIFFERENTIAL ABSORPTION TEST Complement is inactivated by heating the test serum at $56^{\circ} \mathrm{C}$. for 30 minutes. Samples of the inactivated serum, each of $0.25 \mathrm{ml}$., are then added to $(a) 0.25 \mathrm{ml}$. of guinea-pig kidney emulsion (a $20 \%$ emulsion in saline, Oxoid) and (b) $0.25 \mathrm{ml}$. of oxcell suspension (a $20 \%$ suspension in normal saline with $0.5 \%$ phenol as preservative, Oxoid). Absorption is allowed to proceed in both mixtures for one hour at room temperature before centrifuging. To the first of a series of 10 tubes $(2 \times 0.5)$, each tube containing $0.25 \mathrm{ml}$. of normal saline, is added $0.25 \mathrm{ml}$. of the supernatant from the guinea-pig kidney absorbed serum and then doubling dilutions made. Then $0.25 \mathrm{ml}$. of a freshly prepared $1 \%$ sheep cell suspension is added to each tube, thus giving 10 final dilutions ranging from $1: 8$ to $1: 4,096$. After mixing thoroughly, the test is left standing for 18 hours at room temperature before reading the end point of the titration, which is recorded as the last dilution showing macroscopic agglutination. The same procedure is followed in a second series of tubes except that the serum absorbed with ox cells is used. In this laboratory, the lowest titres accepted as being diagnostic are 1:64 before and 1:32 after absorption by guinea-pig kidney.

SERA TESTED Two groups of sera were investigated: (a) control sera obtained from specimens submitted to the laboratory for miscellaneous serological tests including serum protein and electrophoretic analysis; and (b) 'suspect' sera obtained from patients with clinical and/or haematological features suggestive of infectious mononucleosis. Approximately $80 \%$ of all the sera tested were submitted by general practitioners in the North-Eastern Region.

All sera were screened by both the horse-cell and sheepcell slide techniques and a differential absorption test was subsequently carried out on the sera reacting positively with both or either of the screening tests. 
For the purpose of this comparative study, the diagnosis of infectious mononucleosis was established solely on the basis of the conventionally accepted differential absorption test. That is, a patient showing the clinical and/or haematological features of the disease was considered to have the disease only if the differential absorption test was positive.

\section{RESULTS}

CONTROL SERA Of 1,000 control sera (Table I), five gave a positive horse-cell and 77 a positive sheep-cell screening test. One serum, that from patient 1 (see below), gave a positive reaction with both screening tests and a titre of 1:128 with the differential absorption test. This patient was regarded as an unsuspected but proven case of infectious mononucleosis.

Of the four remaining sera reacting positively with the horse-cell antigen, none gave a corresponding reaction with the sheep-cell screening test or a diagnostic titre with the differential absorption test. Two of these positive reactions were associated with dysproteinaemias and autoimmune phenomena (patients 2 and 3), one with infective hepatitis (patient 4), and the other with rheumatoid arthritis (patient 5), although in this instance the patient may have been a convalescent case of infectious mononucleosis.

Of the 77 sera reacting positively with the sheepcell screening test, none gave a corresponding reaction with the horse-cell antigen or a diagnostic titre with the differential absorption test apart from the serum of patient 1 . No correlation was found to exist between the false positive reactions encountered with the sheep-cell test and the result of the tests originally requested.

As can be seen from Table I, the number of false positive reactions encountered with the horse-cell screening test $(0.4 \%)$ is considerably less than that with the sheep-cell screening test $(7 \cdot 6 \%)$.

Patient 1 P.J., an 18-year-old female student, was admitted with vomiting, diarrhoea, and colicky abdominal pain of 36 hours' duration. She was a close contact of a patient convalescing from Sonnë dysentery. Clinical examination was normal apart from deep epigastric tenderness. Widal agglutination and repeated stoo cultures for intestinal pathogens were negative. The peri은 pheral blood was normal. The patient's symptoms quickly: subsided and she was discharged five days later. On the? day of discharge, her serum was found to react positively with both screening tests for infectious mononucleosis and a differential absorption test was positive to a titrọ of $1: 128$. She was allowed home but subsequently comब plained of malaise and developed a sore throat with en larged nodes in the posterior cervical and right axillary groups. No further haematological or serological testड़ were made.

Patient 2 M.F., a 67-year-old housewife with chroni $\overrightarrow{E_{0}}$ systemic lupus erythematosus, was admitted with an acute? attack of vomiting and diarrhoea. Stool cultures fo? intestinal pathogens were consistently negative and bein cause all gastrointestinal investigations failed to demonstrate a cause for her symptoms, these werहै attributed to a 'lupoid' crisis. Her serum was found to give a consistently positive reaction with the horse-celf antigen but the sheep-cell screening and differentiap absorption tests remained negative. Apart from a mild normochromic, normocytic anaemia the peripheral bloos was normal. The L.E. cell test showed numerous L.E. cells, including rosette formations. Other serologicalo investigations were: rheumatoid arthritis latex, positive? Rose-Waaler, positive 1:2; L.E. latex, positive; anti nuclear factor, positive; lupus precipitin test, negativeo direct Coombs test, negative. Serum protein estimation and electrophoresis showed hyperglobulinaemia witlo increases in the alpha $a_{2}$ and gamma fractions.

Patient 3 J.C., a 53-year-old woman, was referred fo $\mathbb{Z}$ investigation and treatment of cavitating pulmonary tuberculosis. She also showed clinical features of hypo옥 thyroidism, the late result of radioactive-iodine treatment for thyrotoxicosis. All thyroid antibody tests were nega tive. Peripheral blood examination was normal apart. from a mild hypochromic, microcytic anaemia. Her serund consistently gave a positive reaction with the horse-ce: antigen but the sheep-cell screening and differentiat absorption tests remained negative. Other serological test were: rheumatoid arthritis latex, positive; Rose-Waaler? positive $1: 128$; L.E. latex, negative; lupus precipitin test, positive; antinuclear factor, positive; L.E. cell test? negative. Serum protein estimation and electrophoresis showed hyperglobulinaemia with an atypical gamm? fraction.

Patient 4 J. Mc., a 23-year old man, was admitted as $\cong$ suspected case of infective hepatitis. Before admissiom he complained of tiredness for one month, anorexia and

TABLE I

\begin{tabular}{|c|c|c|c|c|}
\hline \multirow[b]{2}{*}{ Control Sera } & \multicolumn{3}{|c|}{ RESULTS IN 1,000 CONTROL SERA } & \multirow[b]{2}{*}{$\begin{array}{l}\text { Positive Differential } \\
\text { Absorption Test }\end{array}$} \\
\hline & Total & $\begin{array}{l}\text { Positive Horse-cell } \\
\text { Slide Test }\end{array}$ & $\begin{array}{l}\text { Positive Sheep-cell } \\
\text { Slide Test }\end{array}$ & \\
\hline A.S.O. titres & 60 & - & 16 & - \\
\hline Rheumatoid tests & 88 & 2 & 4 & - \\
\hline Thyroid tests & 121 & - & 4 & - \\
\hline Wassermann reactions & 470 & - & 30 & 一 \\
\hline Widal and Brucella agglutinations & 167 & 1 & 16 & 1 \\
\hline Serum protein analyses & 94 & 2 & 7 & - \\
\hline Total & 1,000 & 5 & 77 & 1 \\
\hline
\end{tabular}

RESULTS IN 1,000 CONTROL SERA 
occasional bouts of nausea for two weeks, and had noted jaundice with darkening of his urine for one week. No clinical features of infectious mononucleosis were present, but the liver was enlarged and tender on palpation. Serological testing revealed a consistently positive horsecell test but negative sheep-cell and differential absorption tests. The peripheral blood showed a normal red cell picture; the total W.B.C. count was $5,900 /$ c.mm. (neutrophils $37 \%$, monocytes $4 \%$, lymphocytes $59 \%$ ). Occasional Türk, but no diagnostic 'glandular-fever' type cells were noted in the film. The serum bilirubin level was $10 \mathrm{mg}$. $/ 100 \mathrm{ml}$., the alkaline phosphatase $23 \mathrm{~K}$.A. units, and the SGOT and SGPT were 235 and 453 units respectively. Clinical and laboratory findings were accepted as being consistent with infective hepatitis. On his discharge from hospital one month later, the patient felt well and the liver function tests had almost completely reverted to normal. The horse-cell screening test, however, remained positive.

Patient 5 W.F., a 38-year-old man, known to have had rheumatoid arthritis for four years, was admitted with an exacerbation of the joint symptoms. Clinical examination, however, revealed enlarged, discrete nodes in both groins and axillae. The liver and spleen were impalpable. His serum consistently gave a positive reaction with the horse-cell test but negative results with the sheep-cell and differential absorption tests. The peripheral blood was normal apart from a slight neutrophilia. The serum proteins were quantitatively and electrophoretically normal. The rheumatoid arthritis latex test and RoseWaaler tests were positive. The patient recalled that he had a febrile illness accompanied by a sore throat three months before admission and hence it was felt that he may have been a convalescent case of infectious mononucleosis. Although his serum is regarded as giving a false-positive reaction, the patient remains under surveillance.

'SUSPECT SERA' Of the 366 sera obtained from patients with a clinical and/or haematological picture suggestive of infectious mononucleosis, 102 reacted positively with both screening tests. Ninety-eight of these gave diagnostic titres with the differential absorption test. Three sera, all from convalescent cases of infectious mononucleosis, gave differential absorption titres of $1: 16$ but as all had previously given diagnostic titres they are not regarded as false positive reactions. The persistence of horse-cell agglutinins after the disappearance of sheep-cell agglutinins in convalescent cases has been reported previously (Barrett, 1941). The remaining serum in this group (patient 6 ) failed to give diagnostic titres although the clinical and haematological features were typically those of infectious mononucleosis.

Ninety-two 'suspect' sera reacted positively with the sheep-cell screening test alone. Two of these sera however, both from adult male patients with short pyrexial illnesses of influenzal type, gave differential absorption titres of $1: 8$ and $1: 16$ respectively. Neither patient had any clinical features of infectious mononucleosis, but both showed a relative lymphocytosis in their peripheral blood. Fourteen days later, the serological tests had become negative and the peripheral blood examinations normal. One further serum in this group, that from a convalescent case of infectious mononucleosis with the unusual complications of myocarditis and neuropathy, gave a consistently positive sheep-cell test with differential absorption titres varying from $1: 16$ to $1: 32$ between the fifth and ninth months of convalescence. Earlier in the illness, all serological tests had been positive and the peripheral blood and clinical findings were diagnostic of infectious mononucleosis, hence this serum is not regarded as giving a false positive reaction with the sheep-cell test or a false negative reaction with the horse-cell test.

Only two 'suspect' sera (patients 7 and 8) were found to give positive reactions with the horse-cell test alone. Both are regarded as giving false-positive reactions, although in both instances infectious mononucleosis was strongly suspected on clinical or haematological grounds.

The remaining 170 sera in this 'suspect' group gave negative reactions with both screening tests.

The results of this part of the study reveal an even more highly significant difference in the number of false-positive reactions obtained by the two screening procedures, $92(25.13 \%)$ with the sheep-cell test and three $(0.82 \%)$ with the horse-cell test. Further, the latter three sera were from cases (patients 6,7 , and 8 ), all of whom showed clinical or haematological features highly suggestive of infectious mononucleosis.

Patient 6 R.T., a 15-year-old girl, complained of malaise for two weeks before developing a low-grade pyrexia and sore throat with bilateral enlargement of cervical lymph nodes. The liver and spleen were not palpably enlarged. Following a five-day course of pencillin which brought about no clinical improvement, blood was submitted for laboratory examination. Both screening tests for infectious mononucleosis were positive but the differential absorption titre before and after absorption with guineapig kidney was only $1: 16$. The total white cell count was $7,200 /$ c.mm. (34\% neutrophils, $3 \%$ eosinophils, $60 \%$ lymphocytes, and $3 \%$ monocytes). Fairly numerous mononuclear cells of 'glandular-fever' type were seen in the stained film. These tests were unchanged when repeated 10 days later. Final follow-up examination after two months showed all three serological tests to be negative and the white cell picture normal.

Clinically and haematologically this patient was accepted as having infectious mononucleosis, but in this study the serum is regarded as giving a false-positive reaction because of the repeated failure to demonstrate a diagnostic titre with the differential absorption test.

Patient 7 J.O., a 26-year-old woman, had a febrileillness accompanied by enlarged cervical nodes, a mild pharyngitis, and an enlarged and tender spleen. The patient's 
sister had recently recovered from infectious mononucleosis, proven by serological and haematological tests. The patient's serum, first examined four weeks after the onset of symptoms, gave a positive reaction with the horse-cell test but negative sheep-cell and differential absorption tests. The total white-cell count was 5,500/ c.mm. (58\% neutrophils, $2 \%$ eosinophils, $30 \%$ lymphocytes, and 10\% monocytes). No diagnostic 'glandularfever' type cells were seen in the stained film. At final follow-up examination two weeks later, the serological results were unchanged.

Patient 8 M.A., a 20-year-old woman, who was on a prolonged course of Griseofulvin for a chronic dermatophytosis, developed pyrexia, with pharyngitis and a few enlarged nodes in both posterior cervical chains. There was no palpable enlargement of the liver or spleen. The patient's serum reacted positively with the horse-cell test alone. The total white cell count was $5,200 / \mathrm{c} . \mathrm{mm}$. (65\% neutrophils, $32 \%$ lymphocytes, and 3\% monocytes). Occasional mononuclear cells, morphologically indistinguishable from 'glandular-fever' type cells, were present in the film. The tests, when repeated 10 days later, remained unchanged. No further follow-up investigations were made.

The comparative studies just described clearly reveal the greater 'specificity' of the horse-cell screening test and the method was therefore adopted as the routine screening procedure in this laboratory.

Since then, a further 565 'suspect' sera have been examined, 141 of which were found to give a positive slide-test reaction. One hundred and thirty-four of these had diagnostic differential absorption titres and another seven, all from convalescent patients with previous levels ranging from $1: 128$ to $1: 4,096$, gave titres of $1: 16$ or $1: 32$. The remaining serum (patient 9), in this positively reacting group, failed to give a diagnostic titre with the differential absorption test although the clinical and haematological findings were typically those of infectious mononucleosis.

Patient 9 J.P., a 6-year-old girl, presented with sore throat, low-grade fever, and moderate enlargement of cervical and axillary lymph nodes. The spleen was palpably enlarged. The horse-cell test was strongly positive but the differential absorption titre was only $1: 16$. The total white cell count was $9,400 /$ c.mm. (5\% neutrophils, $94 \%$ lymphocytes, and $1 \%$ monocytes). Numerous 'glandular-fever' type cells were present in the stained film. The serological tests gave identical results when repeated after intervals of 10 and 28 days, when clinical recovery was complete and the white cell picture normal.

\section{CONCLUSIONS}

The present study on control and 'suspect' serum groups clearly establishes the horse-cell slide test as the more 'specific' screening procedure and defines its diagnostic accuracy as closely approximating to that of the conventional differential absorption test.
These findings support the claim of Hoff and Bauer⿳亠丷厂 (1965) that the new test is more 'specific' than the presumptive sheep-cell test.

The low incidence of false-positive reactions en $=\frac{\text { ? }}{-}$ countered with the new technique considerably reduces the number of sera subsequently requiring differential absorption tests, the practical importance of which lies in the ever-increasing number of requests for serological investigation of suspectedes cases of infectious mononucleosis. The dimension of $\overrightarrow{0}$ this increase is reflected by our findings in the northeastern area of Scotland where, in the quinquennium ${ }_{\sigma}$ 1943-48, only 79 cases were diagnosed as a result of laboratory investigation (Fullerton and Smith, 1951) In comparison, during the period of 1960-64, 398. cases were found in the 2,992 heterophile antibody tests carried out in the same laboratory (Table II).

TABLE II

\begin{tabular}{|c|c|c|c|c|c|}
\hline RESULTS & WITH & LIDE T & т 196 & & \\
\hline & 1964 & 1963 & 1962 & 1961 & 1960 \\
\hline $\begin{array}{l}\text { Total sera tested for } \\
\text { infectious mononucleosis }\end{array}$ & 813 & 767 & 545 & 514 & 353 \\
\hline Positive tests & 101 & 102 & 61 & 81 & 53 \\
\hline Negative tests & 712 & 665 & 484 & 433 & 300 \\
\hline
\end{tabular}

If further experience confirms the high diagnostic气

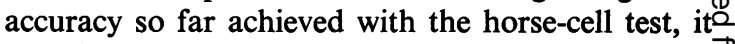
may be assumed that differential absorption tech $\overrightarrow{\overrightarrow{0}}$ niques will become largely, if not completely, un 3 necessary for the routine diagnosis of infectious mononucleosis, although they will continue to be used for obtaining titres of positivity when these ares required for comparative purposes.

Apart from its diagnostic accuracy, the horse-celB slide test is rapid and requires no specialized tech-i nical skill in its performance. Further advantages, especially in epidemiological and paediatric work, 0 are that the amount of serum required for the test? is easily obtainable from a fingerprick sampleo collected in a capillary tube, and the serum requires no heat inactivation of complement.

I would like to thank Messrs. S. Main and A. Gray for technical assistance.

\section{REFERENCES}

Barrett, A. M. (1941). J. Hyg. (Lond.), 41, 330.

Bender, C. E. (1958). Ann. intern. Med., 49, 852.

Davidson, I. (1937). J. Amer. med. Ass., 108, 289.

-, and Lee, C. L. (1964). Amer. J. clin. Path., 41, 115.

Evans, A. S. (1960). Amer. J. Hyg., 71, 342.

Fullerton, H. W., and Smith, J. (1951). In Modern Practice in Infectious Fevers, edited by H. S. Banks, vol. 2, p. 939. Butterworth London.

Hoagland, R. J. (1960). Blood, 16, 1045.

Hoff, G., and Bauer, S. (1965). J. Amer. med. Ass., 194, 351.

Moloney, W. C., and Malzone, L. (1949). Blood, 4, 722. 